\author{
олена ДУДНИк, \\ orcid.orq / 0000-0003-1013-1170 \\ кандидат історичних наук, \\ Уманського державного педагогічного \\ університету імені Павла Тичини \\ (Україна, Умань) \\ dudnyk_olena@ukr.net
}

\title{
«ПРОСВІТА» УМАНЩИНИ ЗА ЧАСІВ УКРАЇНСЬКОЇ ЦЕНТРАЛЬНОЇ РАДИ
}

\begin{abstract}
Події Украӥнської революиії 1917-1921 рр. сприяли заснуванню просвітницьких організацій, які своїм основним завданням вбачали надання різної допомоги населенню на ниві культурно-освітніх справ. У статті досліджується прочес утворення товариств «Просвіта» в Уманському повіті Київської губернії. 3 огляду на вагомість реалізованих проектів в статті увага присвячена добі Центральної Ради.

Базуючись на архівних документах та матеріалах періодики, з'ясовано, щзо організаційні заходи $з$ відродження просвітницького руху в Київькій губернії були започатковані відразу після зміни політичного режиму. Головну увагу «Просвіти» краю приділяли праці в українських селах. У публікації встановлено, щзо просвітнищькі організації в повіті почали виникати завдяки народній ініціативі, передусім проявам організаційних зусиль національно налаштованої місцевої інтелігенції та сільської молоді. Встановлено, щзо у більшості сіл Уманського повіту «Просвіти» виступали єдиними структурами, які проводили активну роботу серед населення, їх діяльність фокусувалася у культурнищькій і освітній площчні. Одним із головних завдань, щзо стояли перед просвітянами, було відкриття власних книгозбірень або бібліотек-читалень, придбання літератури $і$ періодичних видань, організачія курсів украӥнознавства, поширення освітніх знань серед населення тобто все те, щзо могло сприяти пробудженню національної свідомості украйнців краю та їх об'єднанню. Фінансова допомога просвітянам краю надавалася органами місцевої влади, самоврядувань, окремими громадянами.
\end{abstract}

Ключові слова: «Просвіта», Уманський повіт, Київьька губернія, культурно-освітня політика, Центральна Рада.

Olena DUDNYK, PhD in History,

Pavlo Tychyna Uman State Pedagogical University (Ukraine, Uman) dudnyk_olena@ukr.net

\section{«PROSVITA» IN THE UMAN COUNTIE DURING THE UKRAINIAN CENTRAL RADA}

The events of the Ukrainian Revolution of 1917-1921 contributed to the establishment of educational organizations, whose main task was to provide various assistance to the population in cultural and educational affairs. The article examines the formation of «Prosvita» societies, their number in the Uman countie of Kyiv province The southern lands of Kyiv region served as a cradle in the formation of the Ukrainian national liberation movement in the historical destiny of Ukraine. The article focuses on the era of the Central Council taking into consideration the importance of the implemented projects. Based on archival documents and periodicals, it was found that organizational measures to revive the educational movement in countiei of Kyiv province had been initiated immediately after the change of political regime. The main attention of "Prosvita" in the region was paid to works in Ukrainian villages. The publication finds that educational organizations in the region began to emerge due to popular initiative, primarily manifestations of organizational efforts of nationally oriented local intelligentsia (teachers, officials) and rural youth. Well-known public figures provided practical assistance in the development of the educational movement. The cultural and educational work of educational societies in the province was especially intensified after the proclamation of the First Universal of the Central Rada and the All-Ukrainian Congress of Societies (June 1917). It was stated that "Prosvitas» were the only structures that carried out active work among the population, their activities were focused on the cultural and educational level in most villages of the Uman countie of the Kyiv province.An important and logical of work of the "Prosvita» of social and educational life of Uman region was the organization of courses in Ukrainian 
studies. the lask of Ukrainian textbooks hampered the ukrainianzation of the scool so members of the «Prosvita» took an aktivte part in creating educational and methodological support for educational institutions/ One of the main tasks facing the educators was to open their book collections or reading libraries, purchase literature and periodicals, organize courses in Ukrainian studies, disseminate educational knowledge among the population, i.e. everything that could help awaken the national consciousness of Ukrainians in the region. Financial assistance to the educators of the region was provided by local authorities and governments, and individual citizens.

Key words: «Prosvita», Uman countie, Kyiv province, cultural and educational policy, Central Rada.

Постановка проблеми. Революційні події 1917-1921 pp. сприяли суттєвим національно-демократичним перетворенням у різних сферах суспільного та культурно-освітнього життя України. Важливою частиною суспільного життя українців в добу Української революції була діяльність культурно-просвітніх самоврядних організацій. Своєрідним центром національно-культурного відродження в добу Української Центральної Ради стала культурно-просвітницька благодійна організація «Просвіта».

Повноцінне духовне відродження народу не можна уявити без вивчення історії окремих регіонів, міст і сіл. Реконструкція національно-демократичних перетворень у революційну добу вимагає активізації регіональних досліджень в українській історії. Тому зростає потреба звернутися до досвіду організації і діяльності просвітянського руху в Київській губернії, зокрема в Уманському повіті. Адже цей досвід має для сучасної України не лише наукове, але й практичне значення. Врахування уроків минулого, засвоєння всього цінного i повчального має важливе значення для сучасного державотворення, утвердження демократичних принципів розвитку суспільства.

Аналіз досліджень. Факти про діяльність «Просвіт», їхню роль у становленні культурно-освітнього сегменту української державності в добу національно-визвольних змагань 1917-1921 pр. знаходимо в працях і спогадах безпосередніх учасників революційних подій (В. Винниченка, Д. Дорошенка та ін.) (Винниченко, 1990; Дорошенко, 2007). Певне значення для аналізу діяльності «Просвіти» в революційний час мають синтетичні роботи В. Верстюка (Верстюк, 2004), Я. Грицака (Грицак, 1996), О. Реєнта (Реєнт, 2003), В. Сарбея (Сарбей, 1999) та ін. Частково дослідженням із вказаної проблематики присвячені праці сучасних вітчизняних дослідників - С. Фарини (Фарина, 1993), О. Германа (Герман, 1995), Л. Кравчука (Кравчук, 1996), Т. Осташко (Осташко, 1997) та ін. Зазначені вчені у своїх роботах відводять вагоме місце ролі просвітницьких осередків у національно-демократичних перетвореннях українського народу, аналізують процес утворення «Просвіт» у різних регіонах держави, розкривають форми і методи культурно-освітньої праці просвітян.

Одним з напрямків подальших досліджень може бути заглиблення аналізу просвітянського руху на первинний, локальний рівень його діяльності. Діяльність товариств «Просвіта» на території Київської губернії після Лютневої революції 1917 р. і досі лишається однією з малодосліджених сторінок історії українського національно-культурного руху.

Мета статті. Метою цієї статті $\epsilon$ аналіз розвитку просвітницького руху в Уманському повіті Київської губернії в період Центральної Ради, який базується на архівних документах та матеріалах періодики. 
Виклад основного матеріалу. Паралельно з розгортанням Української революції набирало сили національно-культурне відродження українського народу. Найбільшого впливу на державотворчі процеси в гуманітарній сфері товариства «Просвіта» досягли в початковий період революції, який уособлювався із структурами і діяльністю Української Центральної Ради. В добу Центральної Ради в містечках та селах Уманського повіту Київської губернії відновлювалися та створювалися осередки «Просвіт», які мали суттєвий вплив на розвиток національної освіти і культури в краю. Так, 8 березня 1917 р. у відозві Товариства українських поступовців «До українського громадянства» був заклик: «Відживляйте і засновуйте «Просвіти» й інші товариства, бо в них осередок культурної праці та початок організації наших сил» (Адамський, 2018: 5).

В Київської губернії осередки «Просвіт» закладаються вже в квітні 1917 р. Головну увагу «Просвіти» приділяли праці в українських селах. Це було дуже важливо в справі відродження національної справи, оскільки в соціальній структурі українського суспільства селянство становило виняткову більшість. Тому стояло завдання залучити широкий загал сільського населення до вирішення проблем національно-визвольної боротьби. На думку В. Лозового, основною організаційною формою залучення селянства до участі в державотворчому процесі мали стати товариства «Просвіта» (Лозовий, 2006: 3).

У квітні 1917 р. розпочала свою діяльність «Просвіта» в селі Ягубець Уманського повіту. Голова товариства Юстим Велічко передусім звернувся до молоді, яка закінчила або ж навчалася у двокласній школі, із розповіддю про завдання «Просвіти». Молодь села згодилася брати участь у діяльності освітньо-просвітницької організації. Записалися до складу «Просвіти» і літні люди. Було зібрано понад 200 книг, які зберігалися у громадській хаті, виписали газети «Нова Рада», «Народна воля», «Вільна Україна» та інші. В роботі товариства взяли участь 173 його члени. Вони збиралися вечорами у громадській хаті, читали газети, дискутували 3 політичних питань. Для неписьменного дорослого населення влаштовано вечірні курси, на яких вчили писати і читати (ДАКО. Ф. 1. Опис 398. Спр. 8. 17 арк. Арк. 3).

Особливо активізувалася культурно-освітня робота просвітницьких товариств після Всеукраїнського з'їзду товариств (червень 1917 р.), який висунув перед місцевими організаціями таке завдання - прискорити створення бібліотек, клубів, читалень, надавати всебічну допомогу в організації українських початкових шкіл для дітей, курсів ліквідації неписьменності для дорослих та підвищення освітнього рівня військовослужбовців. 20 червня на засіданні п'ятої сесії Центральної Ради делегат від Уманщини Олександр Ільченко повідомляв: «Після відчитання Універсалу на вірність ЦУР присягнули полк, народ і духовенство...Свідомість серед народу шириться. Число «Просвіт» росте» (Вісті з Української Центральної Ради, 1917: 2).

Завдяки народній ініціативі просвітницькі організації почали виникати по всій губернії. Періодичні видання того часу є досить інформативним джерелом щодо розгортання просвітянського руху на місцях. Зокрема, газета «Нова рада» оперативно подавала відомості про створення і активну роботу осередків 
«Просвіти» на Уманщині. 3 цього джерела маємо дані про заснування «Просвіти» протягом червня-вересня 1917 р. у таких селах Уманського повіту: Дмитрушки, Молодецьке (Вісті з краю..., 1917), Юрполе, Папужинці, Беринка, Лащева, та Кам'янече, Соколовка («Просвіта»сві, 1917), Покотилове (Читальня, 1917), а також у містечку Тальне (очолив місцевий вчитель I. Галай) (29 червня в м. Тальному, 1917).

В липневому номері газети «Нова рада» повідомлялося: «В селі Павловці Уманського повіту на Київщині в земській школі засновано товариство «Просвіта». За два дні записалося 70 членів, котрі внесли 30 карбованців грошей. На ці гроші виписано «Вільну Україну», накуплено найпотрібніших книжок. До «Просвіти» записалися тільки молоді сили, котрі з великою охотою приступили до праці... Запис членів 3 кожним днем збільшується» (В с. Павловці..., 1917).

У вересні 1917 року в Київській губернії вже діяло 222 осередки, з них: 69 - в Уманському повіті.

Просвітницькою діяльністю у повітах займалися $\mathrm{i}$ інструктори губернського інформаційного бюро. В Київській губернії працювало 54 інструктори, 3 них 10 - в Уманському повіті. Інструктори поширювали літературу серед населення, організовували мітинги та лекції (Інформаційне бюро при Київській Губернській Земській Управі, 1917).

1 жовтня 1917 року в приміщенні політичного клубу м. Умані відбулися установчі збори членів товариства «Просвіта». Учасники зборів заслухали i обговорили доповідь про основні завдання, схвалили статут та обрали раду товариства. До правління товариства увійшли: М. Крамаренко, 3. Краковецький, В. Шпігель, Ю. Дуброва, В. Цєшковський, М. Піснячевський, О. Мущинський. Головою ради обрали Ф. Ловецького, писарем - С. Іваненка, скарбником - К. Малюшевича. Метою своєї діяльності просвітяни Уманщини визначили: заснувати в місті, селах і містечках повіту українські книгозбірні, провести українізацію місцевих шкіл, влаштовувати для населення вистави, музичні і літературні вечори, лекції, дитячі ранки, тобто все те, що могло сприяти пробудженню національної свідомості українців уманського краю та їх об'єднанню. До складу товариства увійшли 64 особи. Уманська «Просвіта» проводила культурно-просвітницьку роботу серед козаків Маньківки і Канева, влаштовуючи їм лекції і вистави (ЦДАВО України. Ф. 166. Опис 1. Спр. 6. Арк. 62). Товариство проявляло турботу щодо поширення освітніх знань серед населення. 3 цією метою організовувалися курси для дорослих, які працювали в приміщенні чоловічої гімназії. До проведення занять залучалися вчителі середніх шкіл міста, які читали лекції та проводили практичні заняття, що охоплювали спектр знань української мови і граматики, української історії, економічної географії України.

В ці ж дні урочисто відкрито товариство «Просвіта» в селі Верхнячка Уманського повіту. Дали згоду працювати у ньому 30 осіб. У перший же день в селі Ладижинка до «Просвіти» записалися 41 особа, зібрано 91 крб. 96 коп. членських внесків. На ці гроші вирішено передплатити газети та придбати 
українські книжки. За домовленістю бібліотека й читальня розмістилися у місцевій земській школі

Активним членом просвітянської родини Уманщини був В. Дурдуківський - відомий педагог, громадський діяч, один із засновників київської «Просвіти». Володимир Федорович народився в с. Пединівці на Уманщині, у сім'ї священика. Після Української революції став директором Першої української гімназії ім. Т. Шевченка у Києві. В. Дурдуківський підтримував зв'язки з Уманщиною, з іiі громадськими діячами. Він надавав практичну допомогу в становленні «Просвіти» в Умані, надсилав навчальну літературу для учнів та вчителів шкіл повіту.

У доповіді про діяльність Інформаційного бюро при Київській губернській земській управі від 3 вересня 1917 р. зазначалося: «...більше продуктивними виявили себе Селянські Спілки вже через те хоча 6 , що вони об‘ єднують в собі культурно-просвітний, політичний та професіональний елементи, та через те. що у них гуртуються кращі сили села. Просвіти зате виявляють свою діяльність більше усього своїм драматичним відділом i виставами, приносять велику допомогу в поширенню національної ідеї. У Просвітах гуртуються здебільшого богаті селяне і між нами збувають люде, котрі ще недавно були у «Союзі руського народу». Ці люди часто гальмують роботу Просвіт. Взагалі, діяльність Просвіт і Спілок найбільш продуктивна буває там, де на чолі їх стоять інтелігентні сили. На Київщині росповсюдяло Бюро протягом серпня 196.636 українських княжок. Цікаво, що тепер зменшився попит на політично-агітаційні брошури, але зате дуже збільшився попит на шкільні підручники, граматики, популярно-наукові та історичні книжечки» (Інформаційне бюро при Київській Губернській Земській Управі, 1917).

Вагомого значення товариства «Просвіта» надавали бібліотечній та видавничій справам. Практично кожен осередок в повітах Київської губернії долучався до організації власних книгозбірень та відкриття при них читалень.

Важливою подією в культурно-просвітницькому житті населення міста Умані було відкриття у травні 1917 р. міської громадської бібліотеки, яка, за повідомленням газети «Наша бібліотека», відразу ж викликала... наплив читачів і поставила перед правлінням бібліотеки ряд суттєвих і невідкладних завдань.

Ще в кінці 1897 р. за ініціативи місцевої інтелігенції в місті було відкрито громадську бібліотеку-читальню. Це була перша і єдина бібліотека в місті. Однак іiі діяльність проходила у надзвичайно несприятливих умовах. Однією із причин малоефективної діяльності було постійне скорочення асигнувань на їі утримання. У квітні 1914 р. громадськість розпочала збір коштів на зведення власного будинку бібліотеки, добилася виділення земельної ділянки під будівництво. Проте губернатор Київської губернії М. Суковкін своїм розпорядженням призупинив іiї будівництво. I тільки в березні 1917 р. міська дума висловилася за повернення майна бібліотеки колишньому товариству. 1 травня 1917 р. було зірвано печатки і відкрито двері колишнього приміщення, а 25 травня відбулося офіційне відкриття міської громадської бібліотеки, яка упродовж 1917 року значно поповнилась книгами. У іï фонд поступили книги 
колишнього жандармського управління, «Товариства грамотності», яке передало понад 100 книг українською мовою. Фонд нараховував біля 400 українських книжок і 300 журналів. Поповнення бібліотеки проходило за рахунок пожертв різними особами та закладами. Було передано 1540 книг, а присяжні повірені передали 1690 книг i брошур. Працівники бібліотеки підготували новий каталог, було організовано відділ української белетристики, науковий та дитячий відділи. На одному із засідань правління бібліотеки було вирішено придбати книги на єврейській мові для задоволення культурних запитів єврейських читачів. Зросла і загальна чисельність постійних читачів, упродовж семи місяців 3 дня відкриття бібліотеки число читачів зросло до 2505 осіб, з яких майже половину (1160) становили учні.

Важливою й логічною формою роботи товариства «Просвіта» щодо українізації суспільного та освітнього життя Уманщини була організація курсів українознавства. Відсутність українських підручників гальмувала українізацію школи, тому члени товариства «Просвіта» брали активну участь у створенні навчально-методичного забезпечення освітніх закладів.

У добу Центральної Ради товариства «Просвіта» залучали органи державної влади й самі проявляли ініціативу в призначенні на посади вчителів. Уманська «Просвіта» прагнула залучити до педагогічної та культурнопросвітницької діяльності якомога більше вчителів, покладаючи на них важливу роль у розвитку системи української національної освіти та виховання. Безперечно, цей процес не завжди був легким. Самі ж українські свідомі вчителі прагнули брати якнайактивнішу участь у діяльності товариства «Просвіта», оскільки це була справді українська громадська організація, яка намагалася педагогічною та культурно-просвітницькою діяльністю поширити освіту й культуру серед широких верств населення уманського краю.

У час змін суспільно-політичного устрою просвітяни, зазвичай, очолювали шевченківський рух в Україні. Товариство «Просвіта», попри політичну ситуацію, намагалося якомога краще організувати дні пам'яті Великого українського поета. «Просвіти» Уманського повіту у справі піднесення національної свідомості українського народу велику увагу приділяли постаті Т. Шевченка.

Влаштовані просвітянами свята відвідувала значна частина як місцевого населення, так і сусідніх населених пунктів. Так, в Уманському повіті у с. Красний-Кут на такому святі читали реферати про Шевченка, декламували вірші, співали пісні, увечері поставили виставу «Нахмарило». Завершувалися свята роздаванням національно-патріотичної літератури, періодичної преси, зображень Т. Шевченка.

Відзначення шевченківських роковин в добу Української революції 1917 1921 pр. вийшло на якісно новий рівень. Уперше за багато років українці отримали можливість гідно відзначити шевченківські дні. Упродовж майже 150 років шевченківські дні відбувалися часто нелегально; в умовах імперської Росії навіть столітній ювілей було офіційно заборонено відзначати.

Ефективній просвітницькій праці не вистачало фінансового ресурсу. У 1917-1918 pр. «Просвіти» могли покладатися здебільшого на моральну 
підтримку держави, оскільки через важкий фінансовий стан, проблеми 3 державотворенням вона не могла надати їм суттєвої грошової допомоги у здійсненні культурно-освітньої роботи. Утримували просвітянські структури за рахунок кооперативних спілок, добровільних пожертв та членських внесків, розміри яких встановлювали самі просвітяни. На шпальтах тогочасних газет можна відшукати приклади такої допомоги. Так, зокрема «Нова рада» інформувала, що громада і службовці місцевої економії села Шукайвода Уманського повіту на сільському сході постановили заснувати «Просвіту» i бібліотеку. Управитель економії Дамаскин пожертував на книгозбірню 50 крб., бухгалтер - 5 крб., селяни - по 1 крб. Той же управитель пообіцяв на потреби «Просвіти» витратити 3 власних прибутків ще 200 крб. і підтримати ініціативу місцевої вчительки Колосовської щодо створення у селі дитячих ясел «Захоронок» (В Шукайводі, 1917).

Сільський схід села Бабанки цього ж повіту прийняв рішення щодо виділення для роботи місцевого просвітянського осередку 100 крб.

Одним із завдань просвітянських осередків була організація театральної справи. При товариствах утворювалися драматичні гуртки, куди входила місцева інтелігенція та ініціативні селяни; саме вони й репрезентували театральну справу в «Просвітах». В селі Соколівка Уманського повіту просвітяни організували драматичний гурток, який ставив вистави «Москальчарівник», «Бувальщина», «Наталка Полтавка». Просвітяни містечка Тальне за демонстрацію вистави «Батраки» виручили 232 крб. Прибуток використали для поповнення книгозбірні для односельців (Культурно-просвітній гурток..., 1917).

На діяльність товариств значною мірою впливали місцеві умови. «Просвіти» влаштовували різні заходи, щоб збільшити свій бюджет і витрачали кошти лише за потреби.

Висновки. Отже, у добу Центральної Ради осередки товариства «Просвіта» в Уманському повіті стали вагомим чинником провадження на місцях культурно-освітньої політики держави. Якісно іншими стали ознаки суспільно-культурного життя в Україні. Виникнення та поширення «Просвіт» в добу Центральної Ради свідчило про прагнення української інтелігенції до поширення знань серед населення, до пізнання своєї історії, до використання своєї мови. Вперше за сторіччя українська культура вийшла 3 підпілля, українська мова залунала на лекціях, зборах, почали виходити українські книги та газети, були засновані національні школи і дитсадки. У цих проявах зростання національної культури і національної самосвідомості значною $є$ й заслуга «Просвіти» Уманського повіту.

\section{СПИСОК ВИКОРИСТАНИХ ДЖЕРЕЛ І ЛІТЕРАТУРИ}

29 червня в м. Тальному, 1917 - 29 червня в м. Тальному...1917. «Просвіта». Нова Рада. (Киї). 2 липня. Адамський, 2018 - Адамський В. Р. «Просвіти» Поділля в добу Української Центральної Ради (березень 1917 квітень 1918 рр.) : Дослідження. Документи. Матеріали. Хмельницький: ФОП Цюпак А. А., 2018. 478 с. В Шукайводі, 1917 - В Шукайводі... 1917 - «Просвіта». Нова Рада. (Киї). 28 квітня.

Верстюк, та ін., 2004 - Верстюк В., Горобець В., Толочко О. Україна і Росія в історичній ретроспективі. Українські проекти в Російській імперії. К., 2004. 504 с. 
Винниченко, 2007 - Винниченко В. Відродження нації. Репринт. відтвор. вид. 1920 р. : у 3 ч. К. : Вид-во політ. л-ри України, 1990. Ч. III. 542 с.

Герман, 1995 - Герман О. М. Діяльність товариства «Просвіта» на Поділлі наприкінці XIX і в першій половині ХХ століття: дис. ... канд. іст. наук: 07.00.01. Чернівці, 1995. 228 с.

Грицак, 1996 - Грицак Я. Нарис історії України. Формування модерної української нації у XIX-XX ст. К. : Генеза, 1996. 358 с.

ДАКО - Державний архів Київської області.

Дорошенко, 2007 - Дорошенко Д. Мої спомини про недавнє минуле (1914-1920 роки) К. : Темпора, 2007. 632 с. Кравчук, 1996 - Кравчук Л. В. Культуро-творча діяльність та просвітницький рух в період Української державності 1917-1920 рр. : автореф. дис. ... канд. іст. наук: 07.00.01. Чернівці, 1996. 23 с.

Культурно-просвітній гурток, 1918 - Культурно-просвітній гурток...1918. «Просвіта». Нова Рада. (Киї). 25 квітня.

Лозовий, 2006 - Лозовий В. С. Поширення просвітницьких осередків в українському селі в період Центральної Ради (1917 р.). // Освіта, наука і культура на Поділлі: зб. наук. пр. / гол. ред. кол.: П. Т. Тронько. Кам’янецьПодільський: Оіюм, 2006. Т. 7: мат. третього круглого столу «Культура, освіта і просвітницький рух на Поділлі у XVIII - на початку XXI ст.». С. 3-11.

Осташко,1997 - Осташко Т. Товариство «Просвіта» - осередки українського національно-освітнього руху за доби Центральної Ради // Центральна Рада і український державотворчий прочес (до 80-річчя створення Центральної Ради): Матеріали наук. конф., 20 березня 1997 р. НАН України, Ін-т історії України. К., 1997. Ч. 2. С. 272-280.

Реєнт, 2003 - Реєнт О. Україна в імперську добу (XIX - початок XX ст.). К., 2003. 338 с.

Сарбей, 1999 - Сарбей В. Національне відродження України. К., 1999. 335 с.

У містечку Покотилове, 1917 - У містечку Покотилове...1917 - Читальня. Нова Рада. (Київ). 26 червня.

У с. Тихому Хуторі,1917 - У с. Тихому Хуторі...1917 - «Просвіта». Нова Рада. (Київ). 1 жовтня.

Фарина, 1993 - Фарина С. Я. Роль «Просвіт» в українському національно-культурному русі на початку ХХ століття.: дис. ... канд. іст. наук: 07.00.01. Кременчук, 1993. 233 с.

ЦДАВО України - Центральний державний архів вищих органів влади та управління України.

\section{REFERENCES}

29 chervnia v m. Talnomu, 1917 - 29 chervnia v m. Talnomu...1917 [June 29 in Talne ...1917]. «Prosvita». Nova Rada. (Kyiv). 2 lypnia. [in Ukrainian].

Adamskyi, 2018 - Adamskyi V. R. «Prosvity» Podillia v dobu Ukrainskoi Tsentralnoi Rady (berezen 1917 - kviten 1918 rr.) [«Enlightenment» Podillya in the days of the Ukrainian Central Council (March 1917 - April 1918)] : Doslidzhennia. Dokumenty. Materialy. Khmelnytskyi: FOP Tsiupak A. A., 2018. 478 s. [in Ukrainian].

V Shukaivodi, 1917 - V Shukaivodi... 1917 [In Shukaivoda ... 1917] - «Prosvita». Nova Rada. (Kyiv).28 kvitnia. [in Ukrainian].

Verstyuk, ta in., 2004 - Verstiuk V., Horobets V., Tolochko O. Ukraina i Rosiia v istorychnii retrospektyvi. Ukrainski proekty v Rosiiskii imperii [Ukraine and Russia in historical retrospective review. The Ukrainian projects in the Russian empire]. K., 2004. 504 s. [in Ukrainian].

Vynnychenko, 2007 - Vynnychenko V. Vidrodzhennia natsii. Reprynt. vidtvor. vyd. 1920 r. [Revival of the nation]: u 3 ch. K. : Vyd-vo polit. l-ry Ukrainy, 1990. Ch. III. 542 s. [in Ukrainian].

Herman, 1995 - Herman O. M. Diialnist tovarystva «Prosvita» na Podilli naprykintsi XIX I v pershii polovyni XX stolittia [Activities of the society «Enlightenment» in Podolia in the late XIX and early XX century]: dys. ... kand. ist. nauk: 07.00.01. Chernivtsi, 1995. 228 s. [in Ukrainian].

Hrytsak, 1996 - Hrytsak Ya. Narys istorii Ukrainy. Formuvannia modernoi ukrainskoi natsii u XIX-XX st. [Essays on the history of Ukraine: the formation of the modern Ukrainian nation of the XIX-XX centuries]. K.: Heneza, 1996. 358 s. [in Ukrainian].

DAKO - Derzhavnyi arkhiv Kyivskoi oblasti

Doroshenko, 2007 - Doroshenko D. Moi spomyny pro nedavnie mynule (1914-1920 roky) [My memories of the recent past (1914-1920)]. K. : Tempora, 2007. 632 s. [in Ukrainian].

Kravchuk, 1996 - Kravchuk L. V. Kulturo-tvorcha diialnist ta prosvitnytskyi rukh v period Ukrainskoi derzhavnosti 1917-1920 rr. [Cultural activity and educational movement in the period of Ukrainian statehood 1917-1920]: avtoref. dys. ... kand. ist. nauk: 07.00.01. Chernivtsi, 1996. 23 s. [in Ukrainian].

Kulturno-prosvitnii hurtok, 1918 - Kulturno-prosvitnii hurtok...1918 [Cultural and educational circle...1918]. «Prosvita». Nova Rada. (Kyiv). 25 kvitnia. [in Ukrainian].

Lozovyi, 2006 - Lozovyi V. S. Poshyrennia prosvitnytskykh oseredkiv v ukrainskomu seli v period Tsentralnoi Rady (1917 r.) [Dissemination of educational centers in the Ukrainian countryside during the Central Rada (1917)]. Osvita, nauka i kultura na Podilli: zb. nauk. pr. / hol. red. kol.: P. T. Tronko. Kam'ianets-Podilskyi: Oiium, 2006. T. 7: mat. tretoho kruhloho stolu «Kultura, osvita i prosvitnytskyi rukh na Podilli u KhVIII - na pochatku KhKhI st.». S. 3-11. [in Ukrainian]. 
Ostashko,1997 - Ostashko T. Tovarystvo «Prosvita» - oseredky ukrainskoho natsionalno-osvitnoho rukhu za doby Tsentralnoi Rady [Society «Enlightenment» is a center of the Ukrainian national educational movement during the Central Rada] // Tsentralna Rada i ukrainskyi derzhavotvorchyi protses (do 80-richchia stvorennia Tsentralnoi Rady): Materialy nauk. konf., 20 bereznia 1997 r. NAN Ukrainy, In-t istorii Ukrainy. K., 1997. Ch. 2. S. 272-280. [in Ukrainian].

Reient, 2003 - Reient O. Ukraina v impersku dobu (XIX - pochatok XX st.) [Ukraine in the imperial era (XIX - early XX centuries)]. K., 2003. 338 s. [in Ukrainian].

Sarbei, 1999 - Sarbei V. Natsionalne vidrodzhennia Ukrainy [National revival of Ukraine]. K., 1999. 335 s. [in Ukrainian].

U mistechku Pokotylove, 1917 - U mistechku Pokotylove...1917 [In the town of Pokotylove... 1917] - Chytalnia. Nova Rada. (Kyiv). 26 chervnia. [in Ukrainian].

U s. Tykhomu Khutori, 1917 - U s. Tykhomu Khutori...1917 [In the village of Tykhy Khutir] - «Prosvita». Nova Rada. (Kyiv). 1 zhovtnia. [in Ukrainian].

Faryna, 1993 - Faryna S. Ya. Rol «Prosvit»v ukrainskomu natsionalno-kulturnomu rusi na pochatku KhKh stolittia [The role of «Enlightenment» in the Ukrainian national and cultural movement in the early XIX century].: dys. ... kand. ist. nauk: 07.00.01. Kremenchuk, 1993. 233 s. [in Ukrainian].

TsDAVO Ukrainy - Tsentralnyi derzhavnyi arkhiv vyshchykh orhaniv vlady ta upravlinnia Ukrainy.

УДК 94(477.46)"1921/1923":939.52

Ігор ОПАЦЬКИЙ,

orcid.org/0000-0002-6786-3295

кандидат історичних наук, викладач кафедри історіі України

Уманського державного педагогічного університету імені Павла Тичини

(Україна, Умань)

igor.opatskiy@gmail.com

\section{ГОЛОД 1921-1923 РР. НА УМАНЩИНІ (ЗА МАТЕРІАЛАМИ АРХІВУ РОДИНИ КУРІННИХ)}

У статті проаналізовано еgо-документи родини Курінних (передусім щуоденник Петра Федоровича Курінного та особисте листування йог осина Петра Петровича Курінного). Наголошено на основних причинах голоду 1921-1923 рр., його масштаби на території історичної Уманщчини. Результатом наукової розвідки є систематизація відомостей з архіву родини Курінних про голод, основні заходи більшовицької влади зі збору податків, вилучення продовольства у населення, здійснення репресивних заходів у боротьбі з селянським повстанським рухом.

Ключові слова: Уманщчина, голод 1921-1923 рр., Петро Курінний, білошовицький режим, воєнний комунізм.

Ihor OPATSKYI,

Candidate of Historical Sciences, lecturer of history of Ukraine Department Pavlo Tychyna Uman State Pedagogical University

(Uman, Ukraine)

igor.opatskiy@gmail.com

\section{THE FAMINE OF 1921-1923 IN THE UMAN REGION (BASED ON THE MATERIAL FROM THE KURINNYIS FAMILY ARCHIVE)}

The article analyses the ego-documents of the Kurinnyis family (in the first place, Petro F. Kurinnyi's diary and the personal correspondence of his son Petro P. Kurinnyi). The main reasons for the famine of 1921-1923 and its scale on the territory of the historical Uman region are noted. The result of scientific research is the systematization of 